\title{
Revisiting enterprise politics in the interwar Hungary: The case of The Rimamurány-Salgótarján Iron Works Co.
}

\author{
Worker's lifestyle and rate of living on the colony of the steel factory \\ in Salgótarján before the World War II.
}

\author{
RÉKA VÁRKONYI-NICKEL ${ }^{1}$
}

\begin{abstract}
The Rimamurány-Salgótarján Iron Works Co. in Salgótarján started to run up from 1871. The people who lived in the workers' colony of the Steelworks in Salgótarján differentiated themselves from the rest of the local residents not only spatially but also in their appearance, as a result of their higher standard of living. At the begining of the 20th century the major streets of the colony (Acélgyári Street) had macadam or stoned surface and were lit with public street lightning. The duty of the socalled Dwelling Master was to guarantee neat, clean, tidy streets within the colony. Steelworkers had more opportunity to visit the shops and barbershop than those men who lived within the downtown. This difference was partly due to their higher income and partly due to the fact that the services of the comany's shop and the barber at the colony were much cheaper than those of other local barbers since it was ordered so by factory management. Workers' houses were up to the standards of the time, they did not pay rent or just a very low price and workers had a possibility to build their own garden houses on the land of the company. All this fundamentally changed in the second half of the 1940s owing to post-war lack of raw material and Socialist 'modernization' and uniformization. The period of communist dictatorship after World War II, nationalization of the works and Socialist 'modernization' created trauma at the colony.
\end{abstract}

KEYWORDS: labour history, interwar Hungary, steel works, iron works, lifestile, workers' colony, workers' dynasties

${ }^{1}$ Junior research fellow, Hungarian Academy of Sciences, Institute of Ethnology, HistoricalEthnography Departement. 
www. metszetek.unideb.hu

\section{THEMATIC PAPERS - Worker - life - representation}

\section{ABSZTRAKT}

\section{A két világháború közötti vállalati gondoskodás felülvizsgálata: a Rimamurány-Salgótarjáni Vasmú Rt. példáján keresztül}

A Rimamurány-Salgótarjáni Vasmü Rt. 1871-ben kezdte meg múködését. A salgótarjáni acélgyári kolónián élő munkások élesen elkülönültek a város szélesebb társadalmától, nem csak térben, de megjelenésükben is, magasabb életszínvonaluknak köszönhetően. A 20. század elejére a kolónia föutcájának (Acélgyári út) már szilárd burkolata volt (kezdetben makadám, majd macskakö), és villanyvilágítással is rendelkezett. A lakmesterként aposztrofált tisztségviselő feladata volt a kolónia utcáinak tisztán és rendben tartása. Az acélgyári munkásoknak gyakrabban volt lehetőségük boltban vásárolni, vagy a borbélyt látogatni, mint más kolóniák munkásainak. A különbség részben annak volt köszönhetö, hogy magasabb jövedelemmel rendelkeztek, részben pedig annak, hogy a vállalat által fenntartott élelmiszerüzletben, illetve a vállalati borbélynál olcsóbban jutottak a szolgáltatásokhoz, mint a város más részein. Jó minőségú kolóniai lakásokban laktak, amelyeknek bérlőik voltak (bérleti díjuk elhanyagolhatóan alacsony volt) de lehetöségük nyílott saját kertes ház építésére is a vállalat birtokain. Mindez alapjaiban változott meg az 1940-es évek második felében a háború utáni hiánygazdálkodás és a szocialista "modernizáció" következtében. A második világháborút követö kommunista diktatúra, a gyár államosítása, és a szocialista "modernizáció" traumatikus viszonyokat teremtett az acélgyári kolónián.

KULCSSZAVAK: munkásság történet, két világháború közötti Magyarország, acélgyár, vasgyár, életmód vizsgálat, munkáskolónia, munkásdinasztiák

\section{Introduction}

Although studying industrial labour had been an ideologically loaded and censored field of enquiry before 1989 and, subsequently, it was in a marginal position after the changeover, the history of labour and workers' life has become a well-researched field in Hungary and Europe. In the early 1980s there began an academic discourse on the history of industrial labour that adopted the methodology applied internationally, such as urban anthropology, microhistory and oral history.

Present day Salgótarján is a town with countyrisights in Nógrád county, north Hungary. Salgótarján is surrounded by beautiful forests and hill stopped with castleruins. It wasonly a small village in the middle of the 19 th century, when the first brown-coalmine was opened. The steel works at Salgótarján became operational in 1871 as the iron smelting factory of Association of Iron Works of Salgótarján. The Rimamurány-Salgótarján Iron Works Co. was founded in 1881. Besides the factories at Ózd and Borsodnádasd it included the above-mentioned association of Salgótarján. The company established a colony for its workers, most of whom came from the territory of present day Czech Republic and Slovakia. 


\section{THEMATIC PAPERS - Worker - life - representation}

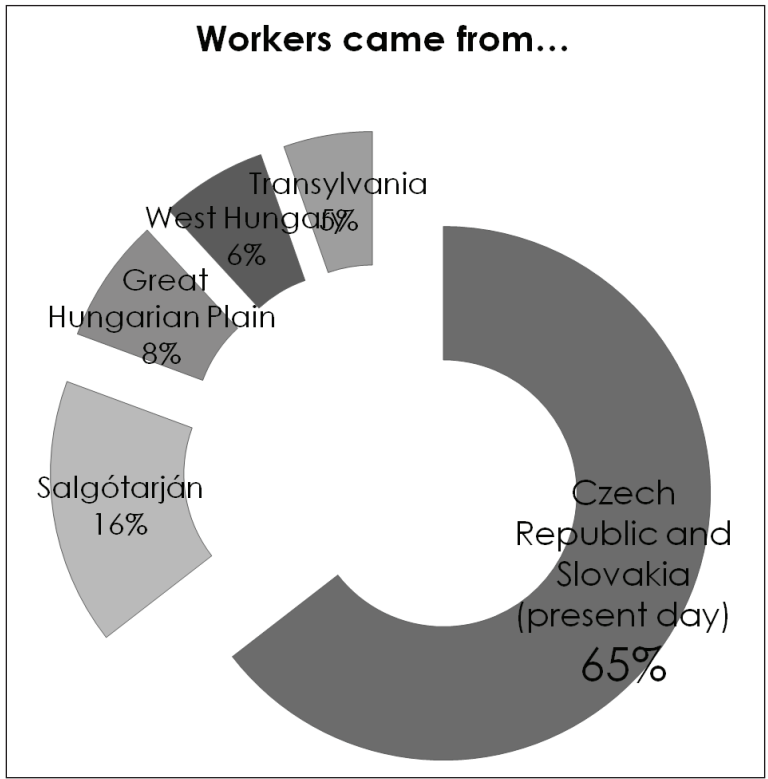

1. diagram. Where the workers of Salgótarján came from in the second half of the 19th century. Source: Edited by the author

The colony was on par with the highest contemporary standards that served as a model with opportunities of doing sports and entertainment. The company recruited skilled labourers for Salgótarján that we may consider first generation workers much like it was customary for military purposes. These workers spoke Slovak, Czech, Italian or German. Subsequently, they started to build community buildings and to create those networks, patterns and norms that social life required. Judit Dobák called attention to the importance of taking generations into account (Dobák 2008). The company supervised these processes. Initially, everyone was newcomer and stranger, thus they formed a separate group in the town. This pattern might have been one of the links connecting workers. The second generation of workers was made up of successors of the group featuring diverse social geographical background. In the late 19th century, efforts of Magyarization were in line with national level tendencies and wished to assimilate multi-lingual families that were also heterogenous in terms of faith. The venue of Magyarization was mainly the Workers Reading Circle that hosted a library and a theatre. Barriers marked the spatial boundaries of the colony of the steel works, while temporally it was the horn signalling the change of shifts that determined daily routine of inhabitants and this is what distinguished them from other groups of the society of the town. 


\section{THEMATIC PAPERS - Worker - life - representation}

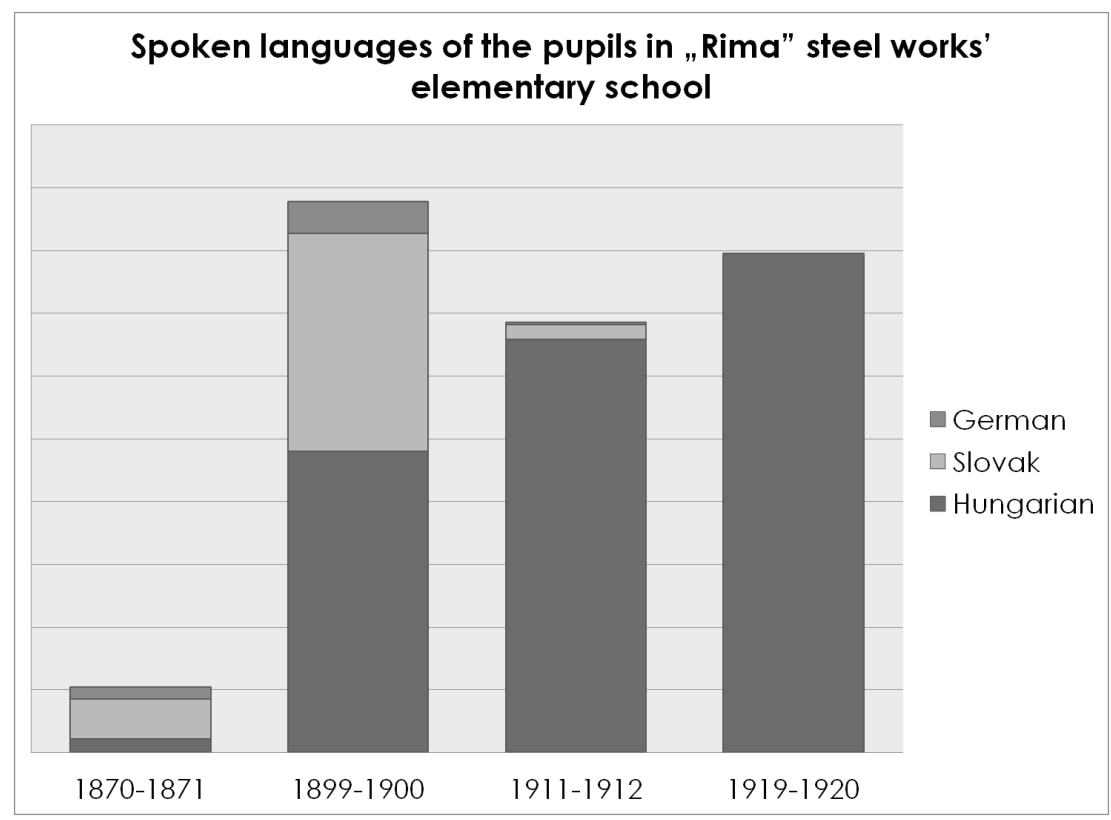

2. diagram. Spoken languages of the pupils in „Rima” steel works' elementary school Source: Edited by the author

From the company management's point of view this picture was close to perfection, although the press of the extreme left tried to challenge this view in the 1950s. During the communist dictatorship, the press had to address the fact that there was a capitalist company where the reason for not having a strong organized labour was simply that workers did not need one (Nagy 2012). Accordingly, physical workers that Népszava interviewed stated that pension, benefit that widow s and orphans received were outrageously low. These workers also complained that the board of directors nominated the managers of workers' funds and members could only select from the list of names provided. According to the paper, workers had doubts about where deductions went.

For analysing the relationship between workers and the employee, we need to take into several elements in their complexity such as salary, work conditions, housing, public hygiene, welfare institutions, education and leisure time. There were national legislation framing this relationship. In the 19th century, contemporaries saw work as part of private life and the regulations were explicitly patriarchic in nature (Bódy 2003). Both parties had obligations for each other. However, based on a liberal concept of law, legislation did not prescribe specific form of these obligations (Bódy 2004). In national comparison, the Rimamurány-Salgótarján Steel Works Co. 


\section{THEMATIC PAPERS - Worker - life - representation}

had extensive set of social institutions. The first elements of these appeared in the early 19th century (Rima 1913, 179).

The contribution of Rimamurány-Salgótarján Steel Works Co. to setting up a system of elementary education was significant in both local and national context. ${ }^{2}$ There was an elementary school at the colony already in the 19th century. Thanks to its equipment and modern outlook, the new school building built in 1929 was outstanding in the opinion of inspectors (MNL OL Z 371 bundle no. 63. folio 140-146. Minutes 1937. április 28.). The number of school that RimamuránySalgótarján Steel Works Co. maintained that outstanding in national comparison. In 1918 the company ran elementary and professional training schools in five buildings. Altogether these had 4060 students and 102 teachers worked for them regularly (Rima 1913). The company laid emphasis on religious moral education of workers and their children. Between 1912 and 1918 they spent $47.571 .32 \mathrm{~K}$ on church buildings.

In 1908 the Company set up an orphanage at Likér with 116 seats. The institution was a world class one. The cost of construction was $300.000 \mathrm{~K}$ (Rima 1913). „The orphanage is up to the standards of modern hygiene in terms of facilities, as it has spacious living room and bedrooms, a pipeline from a spring supplies it with excellent drinking water and the entire building has central heating." (Rima 2013: 36) The orphanage was designed to host 116 children and it was full in 1910. Initially, there were five supervisors attending the children. The orphanage did not work as a school, children went to the company's school.

In 1908 the company built a 'colony of invalids' for ageing workers in a location called Bikás in Zólyom County, using the premises of a former workers' colony of the abandoned factory there. Fifteen houses were renovated and a garden and a piece of land accompanied it. Since workers living in one of the colonies spent a small part of their salary on housing and the company supported cooperative housing, there were few workers that were left without shelter and required the 'invalid colony of Bikás' at old age unless one lost everything at his own fault. „Applicants had to apply to the committee where the pensioner lived. It was the company management that made the decision about the application. The decision is based on there commendation that that committee makes." (Rima 1913: 85)

While studying welfare institutions and benefits, we cannot ignore the issue of leisure. ${ }^{3}$ It was the company management that initiated sports organizations, just like in the case for cultural institutions, at the end of the $19^{\text {th }}$ century. These initiatives were in line with workers' demands. A Reading Hall of Workers' Casino and an Officers' Casino were constructed at the colony of Salgótárján. Sports

\footnotetext{
${ }^{2}$ About the school at Salgótarján see: Balázs 1978; 1979; 1980.

${ }^{3}$ For more details about leasure time activities and culture see: Várkonyi-Nickel 2017.
} 


\section{THEMATIC PAPERS - Worker - life - representation}

associations emerged from the latter. The Reading Hall maintained the library, the music band, the choir and the amateur theatre group. This latter was the first of its kind among workers in Hungary. The company tried to create green areas that served as spaces of recreation. The company created Dolinka Park after World War I in Salgótarján. Next to the hill that was besides the factory they created sports fields and playgrounds. The hill itself was reforested using pine and acacia trees. The fields were under the care of the horticultural department of the factory.

The Rima company established grocery stores in all of its premises. At these shops company employees could buy goods at a reduced price. There was such a shop in Salgótarján, too. (The official denomination of these shops was 'provizorát', while people mostly called them 'magazin' in Salgótarján.) Only employees were entitled to purchase items at the shop and everyone had a credit proportionate to their salary. This credit could not exceed two thirds of the salary. Credit was registered in a booklet. Grocery shops were housed in buildings of various size built for the purpose (Rima 1913). In Salgótarján it was placed in a separate building near the Workers' Casino. In 1928 Ferenc Dullien, the deputy manager of the giant company wrote a description similar to the one written in 1913. Péter Nagy wrote a detailed analysis of this (Dullien 1928 quoted in Nagy 2012). Dullien wrote that Rima created these grocery shops in order to allow workers to buy good quality and clothing at low price at the colony (Dullien 1928 quoted in Nagy 2012). Buildings and facilities belonging to grocery shops belonged to the officers' pension fund. These shops sold their goods at a low interest and forwarded profit to welfare associations: $1 / 3$ went to officer's pension fund, $1 / 3$ went to workers' self-help fund and education fund received the third part (Rima 1913). Ferenc Dullien believed that these were necessary because this was the only way to „avoid excesses of healthy competition” at the colonies (Nagy 2012). Besides foodstuff, shops sold clothes, fruits and cereals. They had contract with butchers in order to secure meat supply (Dullien 1928 quoted in Nagy 2012).

While constructing colonies the company used brick walls and glass windows that could be open, they built at least two rooms (room+kitchen), pavement in front of houses and cleanliness. There was an officer supervising these features, he was called the master of housing. Behind the houses there were shelters constructed for pigs so that families could produce their own meat requirement. They had to turn in meat only during wartime public provisioning. A regulation from 1917 ordered that inhabitants of the colony at Salgótarján should bring the so-called white goods (that is bacon and fat) to the shop, while meat could be sold at 'maximum retail prices' (MNL OL Z 371 63. cs. S-46/22.f. folio 198.).

Shops brought their baked items from the steam bakery of the company (Nagy 2012). They calculated the price of bread taking into account the quality, quantity and price of firewood besides the cost of flour. Company demanded that shopkeepers fully utilize twigs of wood (MNL OL Z 371 S-46/55. f. 1927/1928.). 


\section{THEMATIC PAPERS - Worker - life - representation}

The company had two major grocery shops, one at Ózd and another in Salgótarján. The shop at Salgóbánya belonged to the one at Salgótárján, while the ones at many other locations, Bánszállás, Somsály, Járdánháza, Nádasd, Lucabánya, Likér and Vashegy-Rákos, were under the major shop at Ózd (MNL OL Z 371 S-46/55. f. 1927/1928.).

In 1917 the company launched a soda water factory at Salgótarján to provide drinking water to workers in summer heat. (MNL OL Z 371 63.cs. S-46/22. f. folio 196.) The grocery shops had a shop manager and a cashier who crosschecked each other. Auditing shops was a frequent phenomenon (MNL OL Z 371 S46/55. f. 1925/55.).

Law no. XIV of 1876 about public health, among other things, regulated the issue of vaccination and how a private hospital could be set up. Initially, the Iron Works Association, the predecessor of Rimamurány-Salgótarján Iron Works Co., set up a four-bed sick room next to the school and employed a surgeon. There was not permanent medical doctor at the colony at that time. The company invited Dr. Mihály Jungmann, the first doctor of the town of Salgótarján as medical supervisor. The company hospital and permanent medical care started at the colony shortly after the cholera epidemic of 1872 (Lizsnyánszky - Hortobágyi - Erdős 1968). The hospital had a doctor's office, operating room, a 12-bed male and a 6-bed female ward, bathroom and flats for nurses and doctors. Moreover, it had a park for recovering patients. There was a separate hospital for contagious diseases with 8 beds and flat for nurses. The first doctor of the colony was Dr. Ferenc Vajda.

Starting in 1881, at the hospital of the Rimamurány-Salgótarján Iron Works, there was a personalized precept regulating the tasks of the doctor. Nearly all of these documents survived to this day (MNL OL Z 366 1232. o. sz. 34. cs. Ordersforofficers of RMST -individually. 1899-1939. folio 1306.). The doctor prescribed the diet of each patient and transferred the cost of supplying patients with food on a monthly base. The amount was based on the price list that the committee of the self-help fund sanctioned. The doctor also had public health duties, thus was obliged to visit the homes of workers. He also had to visit the school at least once a month. He also administered smallpox vaccination of children and medically assessed new employees. He had to inform the committee of workers' self-help fund in case he requested leave for the duration of one to three days. Moreover, he also had submit an application to the company management. In that period there was a regulated workers' insurance at the company.

Looking at purchases of the enterprise's hospital at Salgótarján it becomes clear that the company provided support for family members of the insured male when help was needed. Apart from everyday items such as surgical tampon, bandage and various mechanical tools, we find spectacles, artificial eyeballs, orthopaedic and more expensive tools such as walk machines among the items ordered. We always find the beneficiary on the order form. The proportion of male beneficiaries is only 


\section{THEMATIC PAPERS - Worker - life - representation}

cc.50\%, females and children appear nearly just as that frequently. For example, in the hospital ordered a walk machine for 1935 Mrs. Ferenc Sztermen's son for 62 Pengős and social security bore the costs (MNL OL Z 371 62. cs. 1935. szeptember 6.). Moreover, the hospital often turned to the company board of directors for financial assistance, asked for advance payment to finance treatment, but also for the cost of university examinations or for weddings. In the majority of cases the directors entertained these applications. Beneficiaries repaid the loans in monthly instalments (MNL OL Z 371 112. bundle 321. item, Personnel issues 1938.). Among the four company hospitals the one at Ózd was the largest one, Salgótarján was second. It was nuns that undertook nursing duties at both locations. The company hospital worked under close supervision of the board of directors. Medical doctors needed to report nearly all their moves, each treatment and purchase of drugs or equipment to the board of directors and approval was required in advance in most cases (MNL OL Z 371. 62. cs. S-451937. február 8. Dr. János Dörflinger’s letter to general manager and reply 16 February 1937.). Regarding national level figures, there were only 304 hospitals with 50000 beds in total in 1938. Thus, the ratio was 54 beds for 10000 inhabitants. In the Rimamurány-Salgótarján Iron Works's hospital in Salgótarján there were 26 beds for 2100 workers. If we multiply the number of workers by two, that is to count women, then, there were 161 people for one hospital bed. This is better the national ratio (that was 1 to 185), although this was still far from sufficient (MNL OL Z 371. 62. cs. 22 November 1935). In most cases hospitals were overcrowded. The reason behind this was that construction hospitals did not keep pace with the reform of the system of insurance. Associations alone were involved in giving care to the poor. The vast majority of these associations were formed on congregational basis. In Gábor Gyáni' view, social care in Hungary lagged behind Western European standards of the time because there was no pressure on government, moreover conditions were not conducive to the emergence of paternalist social institutions that was typical of businesses of the time (Gyáni 1992). In1918 there was no X-ray in the hospital in Salgótarján, but the hospitals at Korompa and Ózd had such equipment by that time. These institutions of the Rima were proud to be on the list of hospitals where medical students could do their practice (Rima 1913).

Népszava, the communist newspaper mentioned above, dealt with workers' life at Ózd on several occasions. The main thesis of the paper was that working and living conditions at were not satisfactory. One of the articles called workers „slaves of Rima at Ózd" (Among slaves of Rima az Ózd, Népszava 7 October 1928. 9.). According to Népszava, workers „faced death every moment for a salary that equalled the price of one kilogram of bread."(Health and housing snapshots from the Rima empire. Népszava 10 October, 1928.3.)

In the remained of the paper, I take up this assertion and analyse prices at grocery shops and salaries. According to writings of Social Democrats, grocery shop was 


\section{THEMATIC PAPERS - Worker - life - representation}

expensive compared to salaries of workers, thus, employees expressed discontent regarding about them. It is true that local merchants constantly complained about the institution, however they saw unequal competition due to maximized and low prices as the problem (Nagy 2012). We may test these assertions by looking closely at a conflict from 1938.

In that year, the company management required that the price list of the barber shop of the steel works change due to complaint that prices were too low compared to other barber shops in town. The latter feared that they would go bankrupt due to unequal competition. In fact, the barber shop at the colony was still cheaper after the price rise of 1 April 1938 than what would have been desirable for the Trade Group of Salgótarján Barbers. The company's barber shop communicated that that only company employees might use their services. Since 1927 a person called Sándor Cserven managed the company's barber shop. He did not have to pay for rent and electricity. Moreover, he was entitled for $49 \mathrm{q}$ of coal at the price of 20 fillérs. In return, company management had the authority to determine prices at the shop. In an appendix we find a price list that the Trade Group of Salgótarján Barbers established. The graph below shows these prices compared to prices at the company's barber shop in 1938 (MNL OL Z 371 60. bundle S - 27. item). Prices are shown in fillérs (100 fillér = 1 Pengő).

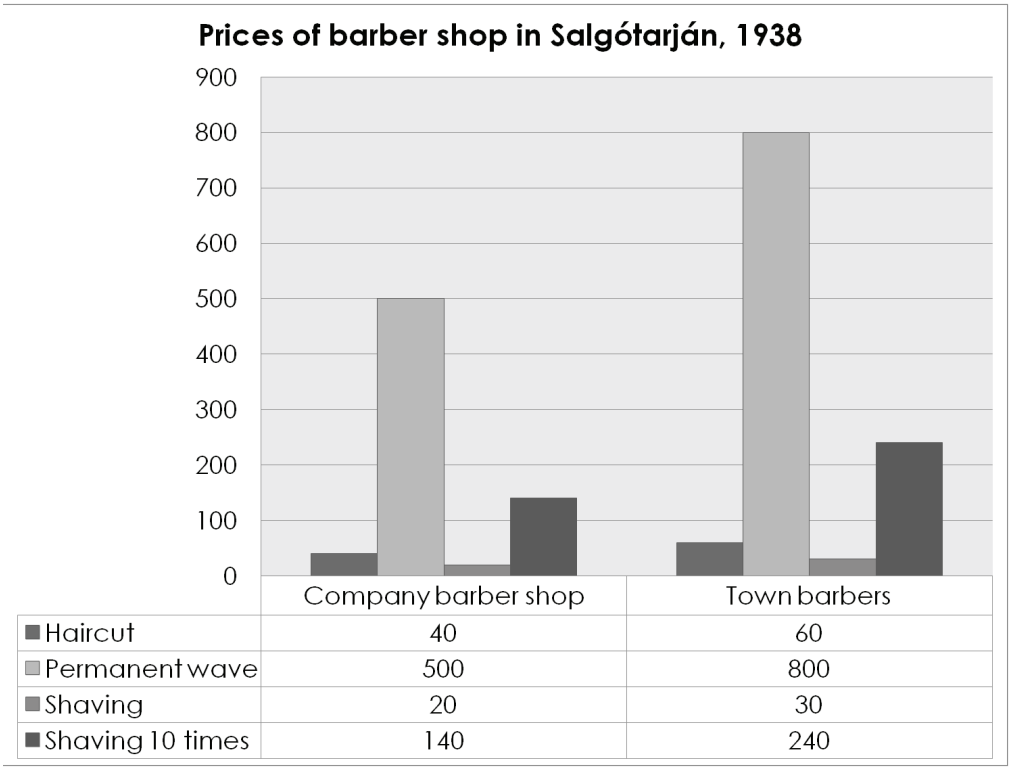

3. diagram. Prices of barber shop in Salgótarján, 1938. Source: Edited by the author 


\section{THEMATIC PAPERS - Worker - life - representation}

It is clear from the graph that there were remarkable differences between prices of the town and the colony. Although town dwellers did not go to company barbers shop, this situation was disadvantageous for town barbers because inhabitants living in the colony would never visit them.

In the next figure I compared national average food prices with prices at the grocery shop from the same year. (Prices are given in fillers.)

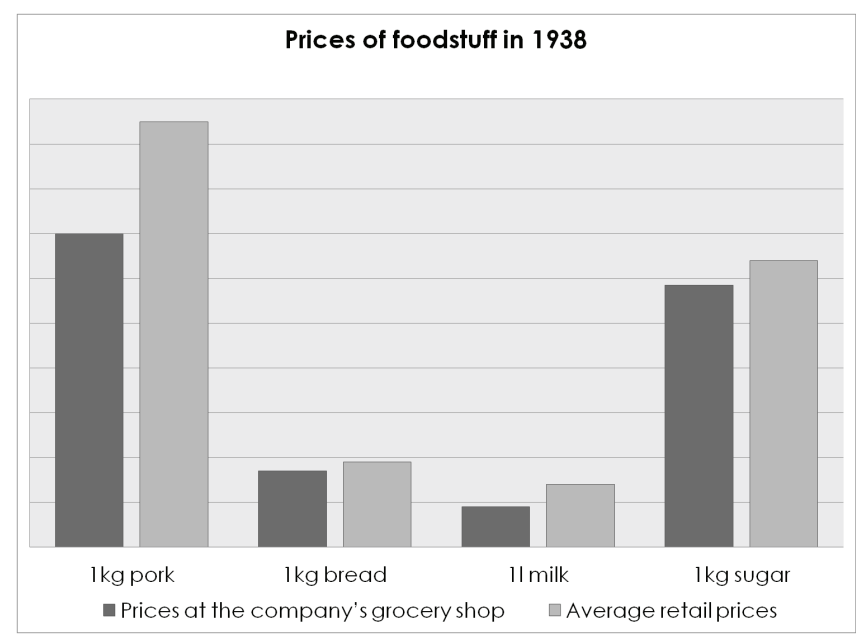

4. diagram. Prices of foodstuff in 1938. Source: Edited by the author

It is clear that prices at the company's grocery shop ${ }^{4}$ were below average retail prices (HungarianYearbook of Statistics, 1938.). Groceryshopsoutsidethecolony of steel works suffered even more than members of the Trade Group of Salgótarján Barbers from the presence of the company's grocery shop since low prices at the ,magazin' obviously deprived them of employees of the steelworks.

In the figure below I just apose average salary at the Rimamurány-Salgótarján Steel Works (MNL OL Z 371 72. cs. Salaryindices- average pay her hour) with national averages that the Statistical Yearbook provided for the same positions in 1938 (HungarianYearbook of Statistics,1938) (in fillérs).

${ }^{4}$ MNL OL Z 371 121. cs. Calculation based on the table of 'Domestic indices' of the report on the economic situation that the Hungarian Economic Research Institute closed for Ózd on 28 February 1939: Weekly expenditure on foodstuff for a five-member family based on prices at grocery shop. 


\section{THEMATIC PAPERS - Worker - life - representation}

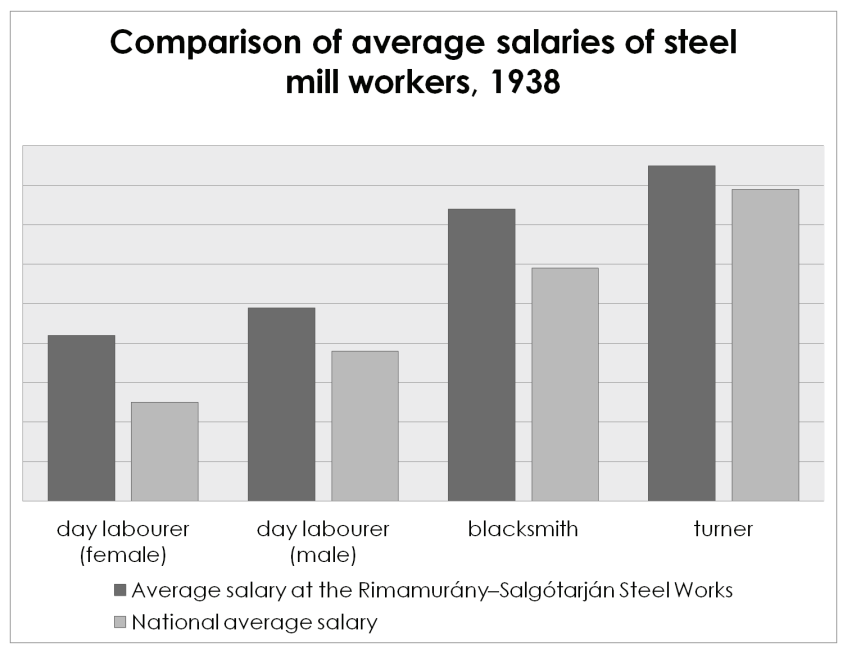

5. diagram. Comparison of average salaries of steel mill workers, 1938 Source: Edited by the author

Based on these data we may conclude that since the price of one kilogram of bread was 34 fillér and the worse paid female day labourer earned 42 fillérs per hour, and the average salary of a skilled labourer was 74 fillérs per hour, they earned significantly more than the cost of bread. In contrast, in Budapest an average female day labourer at mechanical industry earned 25 fillérs, a skilled labourer earned 55 fillérs while bread cost 38 fillérs. Thus, living conditions in Budapest were significantly worse (Hungarian Yearbook of Statistics 1938).

Besides salaries, in kind benefits were not able and inhabitants of the colony were eligibletor receive these to a larger extent than those that lived elsewhere. These benefits amounted to 2 to 5 per cent of the salary. Workers lived in houses built at the colony. They were allowed to stay until they retired that is until they were capable of working. After that date they had to leave. Company distributed flats considering the number of years worked, position, effort and marital status. There were big differences between day laborers, unskilled workers, skilled workers and foremen. Only skilled workers and those in superior positions were entitled to flats in the colony. Others commuted or lived in other parts of the town. Workers' houses were up to the standards of the time and their walls were built of brick. Size, furbishment and distance between the flat and the works reflected status and howlong has one been employed at the works. Workers did not payrent and they only had to payfor a part of expenses including garbage and chimney sweep. Rent was the same in all three colonies (Salgótarján, Ózd, Borsodnádasd). For a oneroom flat workers had to pay 1 Pengő per month, for a 2-room flat they had to pay 


\section{THEMATIC PAPERS - Worker - life - representation}

2 Pengős. There were, however, significant differences in terms of fuel allowances. Workers were entitled for more coal in Ózdon and Borsodnádasd than in Salgótarján and Ózd was the only place where foremen were eligible for firewood free of cost. In other places the company distributed firewood at the price it was purchased. Since Ózd was the largest premises of the works it follows that we find the most differentiated structures there. Fuel entitlements were regulated according to size of flat, and hierarchy at the workplace. In contrast, in Salgótárján and Borsodnádasd only the number of rooms were considered. Although electric lighting was free in all three locations, workers were allowed to use two pieces of $40 \mathrm{~W}$ bulbs at Ózd, while two 25 W ones in Salgótarján and only one at Borsodnádasd. There were differences in terms of the size of plots as well. Ózd each inhabitant of the colony received 77 square feet, in Salgótárján only those were entitled for any land who did not have a garden and the size of plot was about 25 square feet. At Borsodnádasd workers received land only if it laid right next to the colony, although in that case they may have worked a land of 140 square feet.

Working hours and working conditions are important issues as well. The first document that mentioned 8 hours working day and maximized the number of hours worked per week at 48 hours dates from 1919. However, a piece of regulation was not sufficient for making the 8-hour day a practice. At the company at Rimamurány a decree no. 91 dated to 19 December 1918 and the related order no. 11 dated to 11 January 1919 regulated working hours, the 12 hours shifts remained a practice in certain areas during the interwar period..$^{5}$

At Ózd, the 8-hour shift was a general rule in 1938. It was exceeded only in exceptional cases. At the same time, there were units, such as the workshop, at Salgótarján where the working week was 58 hours long instead of 48 hours. Eventually, 8-hour shifts were introduced in Salgótárján in the beginning of 1939 (MNL OL Z 371 52. cs. weekly reports, 2nd week of March 1939). Regulations concerning holidays did not apply to factories that worked incessantly, however there was extra pay for hours worked on holidays and Sundays. Overtime, that is hours worked beyond 8 hours per day or beyond 48 hours per week were compensated with extra, too: $25 \%$ on weekdays and $50 \%$ on Sundays and holidays (MNL OL Z 371 121. cs. 16 December 1937. II. Work on Sundays and holidays, overtime).

Law no. 262 of 1 July 1921 regulated paid leave (MNL OL Z 371 121. bundle. 16 December 1937 III. Paid leave). A worker had to right for 5 days of paid leave if he had been employed for 1 to 5 years, 7 days of paid leave after 5 to 10 of employment and 10 days after 10-15 years of employment. In case a worker had been employed for more than 15 years, she was entitled for 12 days of paid leave per year.If a worker

${ }^{5}$ Collective contract between mining directorate of Rimamurány-Salgótarján Iron Works, assisted by league of mines and smelters of Slovensko co. and the miners of Czechoslovakia, assisted by the district mine council of Bratislava. Part I, Working hours MNL OL Z 371 121. cs. 16 December 1937. 


\section{THEMATIC PAPERS - Worker - life - representation}

was employed for at least two weeks, he was eligible for one week of salary even if he could not work for some serious personal reason unless he caused such an obstacle on purpose or out of carelessness. Such personal life situations could be if his wife gave birth, burial of family member, wedding or being enlisted for military service.

Working conditions were just like in 'Hell'. White-hot steel created extreme heat not only in the furnaces, but also in the rolling mills and in the forging factory. Protective gear was minimal, workers worked steel with their hands, using only hand tools. Cranes were only applied for moving heavy items that human force could not move. Péter Nagy found that among smelters many workers suffered from retinosis that resulted in loss of eyesight (Nagy 2012).

Although I did not find similar data for Salgótarján, we may assume that extreme heat caused this illness there too. The hospital ordered artificial eye balls, besides spectacles, on a regular basis. ${ }^{6}$ Interviewees could not tell me why a person would lose their eye sight? However, memory kept a child with polio and three blind people or ones that had very weak eye sight as examples of serious illnesses and disabilities. Interviewees said that one of the three blind lost his eyesight in World War I, while they could not give reason for the other two cases. The company employed all the three as full time workers. "There were two blind people that worked in the factory. They used to come from the Liptay lane and their task was toput nails into a nailcase. They put nails together for mine-waggons and wagons. The company employed them for 8 hours a day and they would walk to the casino in late afternoon. As far as I can remember, they walked with sticks." (Excerpt from interview with N. Géza14. October 2014. Privatecollection of theauthor.) It is certain that before World War II workers mostly worked without protective gear. My interviewees' tone and gestures suggested that even if there was a protective gear, it was considered manly not to use them. "I do not know where my grandfather started to work, but before his accident he worked at the hot mill in $2 \times 12$ hours shifts. Once he stepped out of the loop too late and the fire snake caught him below his knees. (Hot mill consisted of two rolls. There was a 50 meters distance between the two. Workers placed white hot steel in the rolls and when it came out from the mill, the turner lifted it above his head as if it was a lace, turned it around and placed it back to the rolls. This is how steel became steel bar then steel wire.) After his recovery he worked at the case making factory until his death." (Excerpt from letter from Géza N. to Péter Liptay regarding the manuscript of Rima Sirató 2012. Private collection of the author.)

Industrial supervisors of the district of Budapest regularly visited factories in Salgótárján. 26 October 1937 the supervision found working conditions generally good in Salgótarján's factory, however he still gave a recommendation consisting of 17 items. From the point of view of safety he noted several times that there needs

${ }^{6}$ For example: MNL OL Z 371. 62. cs. S 45/3 12 June 1939. 


\section{THEMATIC PAPERS - Worker - life - representation}

to be boards calling attention to closeness of machines and the danger they posed. Item no. 13 of the list contains a line underlined with pencil,, There should be more showers, toilets and dressing rooms. The layout shall be presented to the district level industrial supervisory authority before execution." (MNL OL Z 371 61. bundleTaxes, excise, benefits, 26 October 1937). The company acted quickly and the layouts were prepared in the same year. The budget included 38000 Pengős for the purpose. They wished to build the washroom at the smelter at the cost of 12700 Pengős.

Taken altogether, work at the steel making factory of Salgótráján required high concentration as work involved several risks and was exhausting. As was the case in both Ózd, and Borsodnádasd, labourers for the Rimamurány-Salgótarján Ironworks Corporation maintained a set of internal workers' welfare institutions. Colony residents were given the opportunity of gaining health and accident insurance, along with membership in a pension fund, and also had access to companymaintained vacation resorts, hospitals, orphanages, and retirement facilities.The company provided opportunities for recreation, leisure, aspects that are still in vogue today. Employees were tied to factory through a number of linkages. They were in contractual relationship as employer-employee and as owner-tenant of flats. At the national level, mandatory insurance and the problems of employees and trade unions showed that Hungary too entered what Zsombor Bódy called the „age of society" (Bódy 2004). At the same time, workers of the colony of the steel workers experienced long working hours and unconditional service to the company in return for material and social security for themselves and their family that exceeded national average. This is in contrast with Zoltán Szabó's view of what he described as the "Rima Empire” where workers lived „under the dictatorship of the company." (Szabó 1938: 152)

Generations were attached to the steel works, so-called workers' dynasties emerged at the colonies. Ageing former workers still talk of themselves as „of Rima" when they tell about of pre-World War II steel works. Belonging to the works became part of their identity. The period of communist dictatorship after World War II, nationalization of the works and Socialist 'modernization' created trauma at the colony. Socialist heavy industry organized production and life of workers based on a different ideology and they denounced workers that were loyal to the capitalist company as „worker aristocrats” and they marginalized them. Their status gradually improved as their professional knowledge was indispensable for production. Subsequently, political changeover and privatization of the 1990s doomed them. The last representatives of workers' dynasties had to struggle with unemployment that had been unknown to them. The last inhabitants of the quarter have to witness the wrecking of 19th century factory buildings of the company that was made to bankrupt. The authors current research focuses on the social, social psychological changes and changes in lifestyle that arise from all these. 


\section{THEMATIC PAPERS - Worker - life - representation}

\section{References}

Balázs, L. (1978): Adatok és összefüggések a Rimamurány-Salgótarjáni Vasmü salgótarjáni (acélgyári) népiskolájának történetéhez (1870-1920). Nógrád Megyei Múzeumok Évkönyve IV., Salgótarján, Nógrád Megyei Történeti Múzeum. 143-156.

Balázs, L. (1979): Adatok és összefüggések a Rimamurány-Salgótarjáni Vasmü salgótarjáni (acélgyári) nép- (elemi) iskolájának történetéhez (1920-1948). Nógrád Megyei Múzeumok Évkönyve V. Salgótarján, Nógrád Megyei Történeti Múzeum. 117-138.

Balázs, L. (1980): Adatok a Rimamurány-Salgótarjáni Vasmű Részvénytársaság iparostanonc-iskolájának történetéhez, Nógrád Megyei Múzeumok Évkönyve VI. Salgótarján, Nógrád Megyei Történeti Múzeum. 161-176.

Balogh, Z. (2012): „Dalra, dalra, ünnepeljünk hát!” A salgótarjáni acélgyári olvasóegylet dalkörének emlékei 1923-1942. Nógrád Megyei Múzeumok Évkönyve XXXV. Salgótarján, Nógrád Megyei Történeti Múzeum. 81-104.

Bikkal, D. (1941): A társadalombiztosítástan története: A társadalombiztosítás elmélete és politikája. Budapest, [kiadó nélkül].

Bódy, Zs. (2003): Egy társadalmi osztály születése. A magántisztviselők társadalomtörténete 1890-1938. Budapest, L’Harmattan.

Bódy, Zs. (2004): A „társadalom kora”. Munkásbiztosítás és munkaügy Magyarországon a 19. és a 20. század fordulóján. Aetas, 19/1. 5-30.

Bódy, Zs. (2010): Az ipari munka társadalma. Szociális kihívások, liberális és korporatív válaszok Magyarországon a 19. század végétől a második világháborúig. Budapest, Argumentum Kiadó.

Dullien, F. (1928): A Rimamurány-Salgótarjáni Vasmű Részvénytársaság szociális és kulturális intézményeinek ismertetése, Munkaügyi Szemle 1928/11. 149-180.

Gyáni, G. (1992): Bérkaszárnya és nyomortelep. A budapesti munkáslakás múltja. Budapest, Magvető Kiadó.

Lizsnyánszky, A. - Hortobágyi, A. - Erdős, I. - Csabai, J. (1968): A Salgótarjáni Kohászati Üzemek száz éve 1868 - 1968. Salgótarján, SKÜ.

Magyar Statisztikai Évkönyv (1938): Magyar Kir. Központi Statisztikai Hivatal, Budapest, Athenaeum.

Nagy, P. (2012): „Ahol a vállalatvezetés volt az úr.... A Rimamurány-Salgótarjáni Vasmű Rt. szociális és jóléti intézményrendszere Ózdon.Korall 13/49.17-36.

Nagy, P. (2015): A gyári munkás és az egészség: Betegségek és balesetek a Rimamurány-Salgótarjáni Vasmű Rt. ózdi munkásai körében. In: Gyimesi, E. Lénárt, A. - Takács, E. (szerk.): A test a társadalomban. (Rendi társadalom - 
www. metszetek.unideb.hu

\section{THEMATIC PAPERS - Worker - life - representation}

polgári társadalom; 27.) Budapest, Hajnal István Kör Társadalomtörténeti Egyesület, 193-203.

Rima [without author] (1913): A Rimamurány-Salgótarjáni Vasmű Részvénytársaság és társvállalatai jóléti intézményeinek ismertetése, Budapest, RMST Rt. Private collection. Alfréd Tetmajer general manager'spapers-Zoltán Nagy's documents.)

Szabó, Z. [1938]: Cifra nyomorúság. Budapest, Cserépfalvi Kiadó.

Szvircsek, F. (1993): A Salgótarjáni Kohászati Üzemek 125 évének története 18681993. Salgótarján, SKÜ.

Várkonyi-Nickel, R. (2015): „Rimai Salgótarján”. A „Rima” munkástelepei és munkáslakásai Salgótarjánban (1871-1945, ETHNOGRAPHIA 126:(4) 597-616.

Várkonyi-Nickel, R. (2017): Rimaiak a gyárak völgyében. Egy salgótarjáni munkáskolónia társadalma az államosítás előtt. Budapest, Néprajzi Értekezések 6., Magyar Néprajzi Társaság.

\section{Archival Sources}

Papers of the Mayor of Salgótarján 1922-1945, Fond no V., Nógrád County Archives of the Hungarian National Archives (hence forth MNL NML)

Hungarian Industrial Companies - Papers of the Rimamurány-Salgótarjáni Iron Works Co. - Steel Factory of Salgótarján 1868-1947.MNL NML XI. S 14.

Papers of the Rimamurány-Salgótarjáni Iron Works Co. - Papers of the Management 1881-1947. Hungarian National Archives Country Archaives (hence forth: MNL OL) Z 371.

Official Documents of the Rimamurány-Salgótarjáni Iron Works Co. 1881-1947. MNL OL Z 366. 